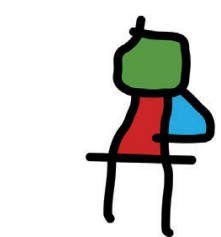

SEICAIP

\section{Allergologia et immunopathologia}

Sociedad Española de Inmunología Clínica, Alergología y Asma Pediátrica

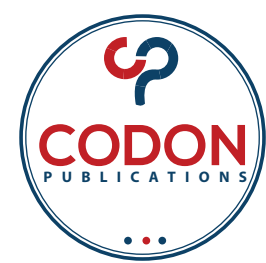

ORIGINAL ARTICLE

OPEN ACCESS (c)

\title{
Treatment with proton pump inhibitors as a cofactor in adverse reactions of patients undergoing oral food immunotherapy
}

\author{
Marta García Vega ${ }^{a *}$, Sara Bellón Alonsob, Amelia Pérez Españac, \\ Sergio José Quevedo Teruelc, Sonia Fernández Fernándeza \\ Teresa Bracamonte Bermejoc, Luis Echeverría Zudairec \\ ${ }^{a}$ Department of Pediatric Gastroenterology, Severo Ochoa University Hospital, Leganés, Madrid, Spain \\ ${ }^{b}$ Department of Pediatric Pneumology, Gregorio Marañón University Hospital, Madrid, Spain \\ 'Department of Pediatric Allergology, Severo Ochoa University Hospital, Leganés, Madrid, Spain
}

Received 6 November 2020; Accepted 17 March 2021

Available online 1 May 2021

\section{KEYWORDS \\ proton pump \\ inhibitors; \\ oral immunotherapy; \\ cofactor; \\ adverse reaction; \\ anaphylaxis; \\ food allergy}

\begin{abstract}
Background and objectives: Based on previous studies revealing acid-suppression medication as a risk factor for food allergy tolerance induction, we aimed to establish the importance of those findings in patients undergoing oral immunotherapy (OIT).

Materials and methods, results: We describe a case series of four patients who underwent milk OIT with a concomitant use of proton pump inhibitor (PPI) medication and who developed anaphylaxis after a known, previously tolerated dose of milk.

Conclusions: PPIs may act as a cofactor in patients undergoing OIT, triggering adverse reactions, irrespective of the PPI used or the dosage. It would be necessary to separate the administration of drug from food intake.

Since OIT is a new form of treatment, long-term adverse events arising from PPI treatment and other possible triggers are still uncertain. Consequently, monitoring of patient must be prolonged over time. Additional investigations on the influence of different drugs in OIT maintenance phase are required.
\end{abstract}

(c) 2021 Codon Publications. Published by Codon Publications.

\footnotetext{
*Corresponding author: Marta García Vega. Department of Pediatric Gastroenterology, Severo Ochoa University Hospital, Leganés, Madrid, Spain. E-mail address: mgarciavega6@gmail.com
} 


\section{Introduction and objectives}

Oral immunotherapy (OIT) with cow's milk may be regarded as an alternative to elimination diet. Multiple studies have demonstrated that OIT could induce desensitization or even sustained unresponsiveness. However, the process is not risk-free. Prolonged maintenance treatment is required, and adverse reactions may occur. Some of these reactions are triggered by known cofactors such as infections, exercise, and nonsteroidal anti-inflammatory drugs. ${ }^{1}$

In addition, the onset of eosinophilic esophagitis (EoE) after OIT has been described, although the relation between them has not been fully assessed. The prevalence of EoE in the general population is estimated at $1.1 \%$ but this increases to $8.3 \%$ in allergic children. ${ }^{2,3}$ A meta-analysis done by Lucendo et al. reported an EoE prevalence of $2.7 \%$ after OIT. ${ }^{4}$ Another prospective study has demonstrated that primary eosinophilic gastrointestinal disorders were diagnosed in $6.25 \%$ of the patients subjected to OIT. ${ }^{5}$

Provided that gastrointestinal symptoms, such as reflux or development of EoE, could occur in the context of OIT, patients would require treatment with proton pump inhibitors (PPIs). PPIs alter the processing of food allergens by activation of conformational changes in food proteins, which could favor their recognition by specific immunoglobulins (Igs). Elevation in the gastric $\mathrm{pH}$ leads to reduced pepsin activation, enabling persistence of ingested epitopes and their uptake in the intestines, resulting in eosinophilic inflammation and allergic symptoms. In addition, the increased gastric $\mathrm{pH}$ results in the persistence of otherwise digestion-labile proteins, which remain stable, and their conformation intact enhances the possibility for de novo sensitization and formation of antigen-specific Ig. ${ }^{6}$

Based on previous studies revealing acid-suppression medication as a risk factor for food allergy tolerance induction, we aimed to establish the importance of those findings in patients undergoing OIT.

\section{Patients}

Our case series includes four patients, aged between 7 and 12 years, who were in the maintenance phase of milk OIT for at least 2 years. They were treated with OIT due to persistent allergy demonstrated by clinical findings, prick testing, specific Ig (i.e., Ig-E), and a positive oral food challenge.

This study was approved by the Clinical Research Ethics Committee of Severo Ochoa University Hospital, Madrid, Spain, and written informed consent was obtained from all patients.

Three of the four patients were diagnosed with EoE and the fourth one suffered from non-eosinophilic gastritis. Diagnosis was made following European guidelines on EoE: symptoms of esophageal dysfunction in combination with eosinophil-predominant infiltration on esophageal biopsy of $\geq 15$ eosinophils per high power field. ${ }^{7}$

Although EoE development in the context of OIT could be a reason to discontinue OIT, there is no consensus regarding management of such patients. In our case, all the patients were initially treated with PPIs because they had been in the OIT maintenance phase for a long time, so a possible causal relationship between OIT and EoE was difficult to establish.
Besides, we were not able to confirm its previous existence since endoscopic study before OIT was not indicated. Moreover, PPI treatment seems to have proved its effectiveness in these patients, reaching rates of success similar to those in EoE patients without OIT history Finally, we considered the importance of making treatment decisions based on family and patient consensus. Clinical practice established that most of these patients were usually reluctant to elimination diet once OIT is successfully carried out.

\section{Results}

Oral immunotherapy was maintained and treatment with PPIs implemented, including omeprazole, esomeprazole, and lansoprazole, using standard or high doses depending on the underlying medical condition. The first drug administration took place between 1 and $4 \mathrm{~h}$ after the daily milk intake. In the following $15 \mathrm{~min}$, patients presented urticaria, angioedema, and respiratory distress.

They received treatment with antihistamines, oral corticosteroids, and bronchodilators with a good and quick response. One of them required intramuscular adrenaline. Symptoms disappeared within the first $24 \mathrm{~h}$. The existence of other known triggering factors was ruled out. Prick tests for PPIs were negative, and oral challenge for the involved drug was performed without immediate or delayed symptoms (Table 1).

\section{Conclusions}

This finding suggests that PPIs could have a role as a cofactor of adverse reactions in patients undergoing OIT.

However, the findings of this study must be seen in the light of some limitations, since it is an observational study with a limited sample size and without a control group.

Oral immunotherapy is a novel form of treatment, and long-term safety is poorly reported, so long-term adverse effects remain unknown, and the possible cofactors and underlying mechanisms are unclear.

Previous studies have revealed that acid-suppression treatment interferes with the digestion of proteins, leading to IgE induction and food allergy. This enhances the possibility for de novo sensitization and formation of antigen-specific Igs, which leads to the promotion of T-helper 2 immune milieu, generating structural changes in the intestinal epithelium. ${ }^{6,8}$

The small intestine is considered the main organ of intolerance development and food allergy induction. Selective intestinal permeability is essential for the uptake of nutrients and oral tolerance. A dysfunctional gastrointestinal barrier has an essential contribution to food allergic reactions. Hypoacidity of the stomach is associated with modified composition of intestinal microbiota. A recent meta-analysis revealed that PPIs have a more prominent effect on microbiota composition than antibiotics. ${ }^{9}$

A study has demonstrated that children with a previous history of taking antacid medication had a greater prevalence of food allergy (57\% vs $32 \%, \mathrm{P}=0.008) .{ }^{10}$ 
Table 1 Clinical characteristics of the study population

\begin{tabular}{|c|c|c|c|c|}
\hline & Case 1 & Case 2 & Case 3 & Case 4 \\
\hline Sex & Male & Female & Female & Male \\
\hline Age (years) & 7 & 8 & 12 & 10 years \\
\hline $\begin{array}{l}\text { Maintenance phase } \\
\text { of cow milk OIT }\end{array}$ & 2 years & 2 years & 6 years & 3 years \\
\hline Disease & $\begin{array}{l}\text { Eosinophilic } \\
\text { esophagitis }\end{array}$ & Gastritis & $\begin{array}{l}\text { Eosinophilic } \\
\text { esophagitis }\end{array}$ & $\begin{array}{l}\text { Eosinophilic } \\
\text { esophagitis }\end{array}$ \\
\hline PPI & Lansoprazole & Omeprazole & Esomeprazole & Esomeprazole \\
\hline Adverse reaction & $\begin{array}{l}\text { Angioedema + } \\
\text { Respiratory } \\
\text { symptoms }\end{array}$ & $\begin{array}{l}\text { Urticaria } \\
\text { + Angioedema } \\
\text { + Respiratory } \\
\text { symptoms }\end{array}$ & $\begin{array}{l}\text { Urticaria } \\
\text { + Respiratory } \\
\text { symptoms }\end{array}$ & $\begin{array}{l}\text { Urticaria } \\
\text { + Respiratory } \\
\text { symptoms }\end{array}$ \\
\hline $\begin{array}{l}\text { Treatment of } \\
\text { adverse reaction }\end{array}$ & $\begin{array}{l}\text { Antihistamines } \\
\quad+\text { Corticosteroids } \\
\text { + Bronchodilators }\end{array}$ & $\begin{array}{l}\text { Antihistamines } \\
\quad+\text { Corticosteroids } \\
+ \text { Bronchodilators } \\
\text { + Epinephrine }\end{array}$ & $\begin{array}{l}\text { Antihistamines } \\
\quad+\text { Corticosteroids } \\
\text { + Bronchodilators }\end{array}$ & $\begin{array}{l}\text { Antihistamines } \\
+ \text { Bronchodilators }\end{array}$ \\
\hline $\begin{array}{l}\text { Time to clinical } \\
\text { resolution }\end{array}$ & $<24$ hours & $<24$ hours & $<24$ hours & $<24$ hours \\
\hline $\begin{array}{l}\text { Time after first } \\
\text { dose drug } \\
\text { administration }\end{array}$ & 1 hour & 4 hour & 2 hour & 1 hour \\
\hline $\begin{array}{l}\text { Time after cow milk } \\
\text { intake }\end{array}$ & 5 minutes & 15 minutes & 15 minutes & 20 minutes \\
\hline $\begin{array}{l}\text { Trigger factor } \\
\text { (exercise, } \\
\text { NSAIDs...) }\end{array}$ & No & No & No & No \\
\hline Prick test for PPIs & Negative & Negative & Negative & Not performed. \\
\hline $\begin{array}{l}\text { Oral challenge for } \\
\text { the PPI involved }\end{array}$ & Negative & Negative & Negative & $\begin{array}{l}\text { Not performed. } \\
\text { Still under treatment. }\end{array}$ \\
\hline
\end{tabular}

In another observational cohort study of 152 patients (none of them with previous history of allergy or atopy), antacid drugs were given for 3 months. IgE sensitization to food allergens was compared before and after the treatment. The relative risk to develop food-specific IgE after treatment was 10.5. The long-term effect was evaluated 5 months after the therapy. Food-specific IgE could still be found in $6 \%$ of the patients as well as elevated serum concentrations of an IL-33 receptor (ST2), a Th2-specific marker. ${ }^{11}$

In mouse models, gavage of digestion-labile food allergens together with antacids resulted in formation of allergen-specific lgE antibodies, positive skin tests, a drop-in core body temperature, and mast cell mediator release, which all are associated with anaphylactic reactions. ${ }^{12}$

In conclusion, the role of PPIs as a cofactor of adverse reactions in patients undergoing OIT is a finding of considerable interest and could have significant implications for clinical practice.

These drugs may be considered as a cofactor, irrespective of the PPI used or the dosage. It would be necessary to separate the administration of the drug from food intake.

Since OIT is a new form of treatment, long-term adverse events arising from PPI treatment and other possible triggers are still uncertain. Consequently, patient monitoring must be prolonged over time.

Additional investigations on the influence of different drugs in OIT maintenance phase are required.

\section{Declarations of interest}

None.

\section{Funding}

This research did not receive any specific grant from funding agencies in the public, commercial, or not-for-profit sectors.

\section{References}

1. Bidat E, Deschildre A, Lemoine A, Benoist G, Valleteau J, Tressol C, et al. Cow's milk protein allergy: A practical guide to the reintroduction of cow's milk proteins - When and how it should be reintroduced. Rev Fr Allergol. 2019;59:41-53. https://doi.org/10.1016/j.reval.2018.11.006

2. Ronkainen J, Talley NJ, Aro P, Storskrubb T, Johansson SE, Lind $\mathrm{T}$, et al. Prevalence of oesophageal eosinophils and eosinophilic oesophagitis in adults: The population-based Kalixanda study. Gut. 2007;56:615-20. https://doi.org/10.1136/ gut.2006.107714

3. Kim JS, Nowak-Wegrzyn A, Sicherer AH, Noone S, Moshier EL, Sampson HA. Dietary baked milk accelerates the resolution of cow's milk allergy in children. J Allergy Clin Immunol. 2011;128:125-31. https://doi.org/10.1016/j.jaci.2011.04.036 
4. Lucendo AJ, Arias A, Tenias JM. Relation between eosinophilic esophagitis and oral immunotherapy for food allergy: A systematic review with meta-analysis. Ann Allergy Asthma Immunol. 2014;113:624-9. https://doi.org/10.1016/j.anai.2014.08.004

5. Echeverría-Zudaire LA, Fernández-Fernández S, RayoFernández A, Muñoz-Archidona C, Checa-Rodríguez R. Primary eosinophilic gastrointestinal disorders in children who have received food oral immunotherapy. Allergol Immunopathol. 2016;44(6):531-6. https://doi.org/10.1016/j.aller.2016.05.002

6. Jordakieva, G., Kundi, M., Untersmayr, E. et al. Countrywide medical records infer increased allergy risk of gastric acid inhibition. Nat Commun. 2019;10:3298. https://doi. org/10.1038/s41467-019-10914-6

7. Lucendo AJ, Molina-Infante J, Arias A, von Arnim U, Dredenoord AJ, Bussmann C, et al. Guidelines on eosinophilic esophagitis: Evidence-based statements and recommendations for diagnosis and management in children and adults. United European Gastroenterol J. 2017; 5:335-58. https://doi. org/10.1177/2050640616689525
8. Diesner SC, Knittelfelder R, Krishnamurthy D, Pali-Schöll I, Gajdzik L, Jensen-Jarolim E, et al. Dose-dependent food allergy induction against ovalbumin under acid-suppression: A murine food allergy model. Immunol Lett. 2008;121:45-51. https://doi.org/10.1016/j.imlet.2008.08.006

9. Imhann F, Bonder MJ, Vich Vila A, Fu J, Mujagic Z, Vork L, et al. Proton pump inhibitors affect the gut microbiome. Gut. 2016;65:740-8. https://doi.org/10.1136/gutjnl-2015-310376

10. DeMuth K, Stecenko A, Sullivan K, Fitzpatrick A. Relationship between treatment with antacid medication and the prevalence of food allergy in children. Allergy Asthma Proc. 2013;34:227-32. https://doi.org/10.2500/aap.2013.34.3657

11. Untersmayr E, Bakos N, Schöll I, Kundi M, Roth-Walter F, Szalai K, et al. Anti-ulcer drugs promote IgE formation toward dietary antigens in adult patients. FASEB J. 2005;19:656-8. https://doi.org/10.1096/fj.04-3170fje

12. Samadi N, Klems M, Untersmayr E. The role of gastrointestinal permeability in food allergy. Ann Allergy Asthma Immunol. 2018;121:168-73. https://doi.org/10.1016/j.anai.2018.05.010 